\title{
Production, purification and characterization of mid-redox potential laccase from a newly isolated Trichoderma harzianum WL1
}

\author{
S. Sadhasivam ${ }^{\mathrm{a}, *}$, S. Savitha ${ }^{\mathrm{a}}$, K. Swaminathan ${ }^{\mathrm{b}}$, Feng-Huei Lin ${ }^{\mathrm{a}}$ \\ ${ }^{a}$ Institute of Biomedical Engineering, College of Engineering, National Taiwan University, Taipei, Taiwan \\ ${ }^{\mathrm{b}}$ Microbial Biotechnology Division, Department of Biotechnology, Bharathiar University, Coimbatore 641 046, Tamil Nadu, India
}

\section{A R T I C L E I N F O}

\section{Article history:}

Received 22 November 2007

Received in revised form 26 February 2008 Accepted 26 February 2008

\section{Keywords:}

Laccase

T. harzianum

Activity

Redox potential

ABTS

$\mathrm{Cu}$

\begin{abstract}
A B S T R A C T
A new strain of Trichoderma harzianum WL1 was isolated from the Western Ghats region of Tamilnadu, India and assayed for laccase activity by ABTS oxidation. Supplementation of $\mathrm{CuSO}_{4}(1 \mathrm{mM})$ in liquid medium yielded high amounts of laccase $\left(4.36 \mathrm{U} \mathrm{ml}^{-1}\right)$ at an incubation period of 4 days. Laccase enzyme produced by $T$. harzianum in cultures supplemented with copper sulphate has been purified by ultrafiltration, Sephadex G-100 column chromatography and Concanavalin-A affinity chromatography with a final purification fold of 151.7 and a yield of $0.39 \%$. The purified enzyme was identified as a glycoprotein with a molecular mass of $79 \mathrm{kDa}$ by SDS gel electrophoresis. The UV-vis spectrum of the purified laccase had a peak at 608 and $325 \mathrm{~nm}$ suggesting the presence of types I and III Cu centers. The redox potential of the enzyme was found to be $692 \mathrm{mV}$ for the type $1 \mathrm{Cu}$ (T1) site. The optimum $\mathrm{pH}$ and temperature for enzyme activity were 4.5 and $35^{\circ} \mathrm{C}$, respectively. Laccase was stable for $24 \mathrm{~h}$ at $35^{\circ} \mathrm{C}$ and had half-life of $60 \mathrm{~min}$ at $65^{\circ} \mathrm{C}$. Purified laccase showed $K_{\mathrm{m}}$ values of 180 and $60 \mu \mathrm{M}$, respectively, and $V_{\max }$ values of 3.95 and $1.42 \mathrm{U} \mathrm{mg}^{-1}$ protein, respectively, for the substrates ABTS and guaiacol. The susceptibility of laccase towards several putative inhibitors and metal cations was also assessed. The enzyme activity was completely inhibited by sodium azide $\left(\mathrm{NaN}_{3}\right)$ at the concentration of $20 \mu \mathrm{M}$. Laccase activity was also inhibited by several metal cations, especially $\mathrm{Hg}^{2+}$.
\end{abstract}

(c) 2008 Elsevier Ltd. All rights reserved.

\section{Introduction}

Laccases (benzenediol: oxygen oxidoreductases, EC 1.10.3.2) are multicopper blue oxidases widely distributed in higher plants, in some insects and in a few bacteria. However the best known laccases are of fungal origin. Laccase production occurs in various fungi over a wide range of taxa. Fungi from the deuteromycetes, ascomycetes as well as basidiomycetes are known producers of laccase [1]. Among them, basidiomycetes are considered to be efficient laccase producers, especially white rot fungi [2]. Well known laccase producers include Trametes versicolor, Chaetomium thermophilum and Pleurotus eryngii. It has been reported that some Trichoderma species, including $T$. harzianum has the ability to produce polyphenol oxidases [3]. In fungal physiology, laccases are involved in plant pathogenesis, pigmentation, detoxification and lignin degradation. All of these functions are related to the oxidation of various organic compounds by means of dioxygen $\left(\mathrm{O}_{2}\right)$, including monophenols, polyphenols, aromatic amines and

\footnotetext{
* Corresponding author. Tel.: +886 9105 30545; fax: +886 23123456.

E-mail address: rahulsbio@yahoo.co.in (S. Sadhasivam).
}

their derivatives, to free radicals, which in turn can undergo both spontaneous chemical and enzymatic reactions [4].

In structural terms, these enzymes can be either monomeric or multimeric glycoproteins, which may exhibit additional heterogeneity because of variable carbohydrate content or differences in copper content [5]. There are many reports on the purification and biochemical characterization of fungal laccases [6,7]. The key characteristics of laccase are the standard redox potentials of its redox centers, the T1, T2 and T3 sites. The types of copper centers (T1, T2 and T3) can be distinguished using UV/vis and electron paramagnetic resonance (EPR) spectroscopy [8]. The redox potential of laccases vary from 0.4 to $0.8 \mathrm{~V}$ and the most critical factor determining the $E^{\circ}$ (laccase) is the coordination sphere of the T1 copper [9].

Laccases catalyze the oxidation of a broad range of substrates such as ortho and para-diphenols, methoxy-substituted phenols, aromatic amines, phenolic acids and several other compounds coupled to the reduction of molecular oxygen to water with the one electron oxidation mechanism. The substrate specificity of laccases varies from one organism to another. The spectrum of laccaseoxidizable substrates can be expanded considerably in the presence of appropriate redox mediators [10]. Due to their interesting catalytic properties laccases have gained considerable interest in 
various industrial areas. The most intensively studied applications have included development of oxygen cathodes in biofuel cells, biosensors, labeling in immunoassays and organic synthesis through biocatalysis. Due to their broad substrate specificity, laccases might have great potential in varied environmental applications including pulp delignification, textile dye bleaching and xenobiotics degradation [11,12]. These applications stimulate new waves of fundamental research concerning this enzyme.

The current research activity of laccases includes screening of laccase sources, studying new laccases and investigating the electrochemical properties of laccases. Laccases of basidiomycetes and ascomycetes are extensively studied and only few reports are available with respect to deuteromycetes laccase. Although there are also some reports on laccase activity in Trichoderma species, the purification and characterization of the purified laccase have not yet reported $[13,14]$. In this study, the biochemical and physicochemical characterization of laccase from the fungus Trichoderma harzianum WL1 with respect to production, purification, redox potential, kinetic and stability properties were reported.

\section{Materials and methods}

\subsection{Chemicals}

Unless otherwise stated all chemicals were purchased from Sigma-Aldrich, USA and were certified reagent grade.

\subsection{Microorganism and growth conditions}

The test fungus Trichoderma harzianum WL1 was isolated from the Western Ghats region of Tamilnadu, India [15] and is placed in microbial culture collection, Microbial Biotechnology Laboratory, Department of Biotechnology and Bharathiar University, India. The fungus was identified as Trichoderma harzianum according to its morphological characteristics [16]. The fungus was maintained on Czapek Dox agar plates at $30^{\circ} \mathrm{C}$. After 6 days of incubation, the spores were harvested without disturbing the mycelial growth using a camel hairbrush and filter-sterilized. The inoculum volume $\left(2.0 \mathrm{ml}\right.$ of $10^{5}$ spores $\left.\mathrm{ml}^{-1}\right)$ was used as standard inoculum for further studies.

\subsection{Production of laccase}

For laccase production, T. harzianum grown on Czapek-Dox agar plates were used to inoculate 250 Erlenmeyer flasks containing $100 \mathrm{ml}$ of liquid culture medium [17]. The medium used had the following composition $\left(\mathrm{g} \mathrm{l}^{-1}\right)$ : 3.0 glucose, $1.0 \mathrm{KH}_{2} \mathrm{PO}_{4}$ $0.26 \mathrm{NaH}_{2} \mathrm{PO}_{4}, 0.317\left(\mathrm{NH}_{4}\right)_{2} \mathrm{SO}_{4}, 0.5 \mathrm{MgSO}_{4}, 0.5 \mathrm{CuSO}_{4}, 2.2$ dimethyl succinic acid $0.74 \mathrm{CaCl}_{2} \cdot 2 \mathrm{H}_{2} \mathrm{O}, 0.006 \mathrm{ZnSO}_{4} \cdot 7 \mathrm{H}_{2} \mathrm{O}, 0.005 \mathrm{FeSO}_{4} \cdot 7 \mathrm{H}_{2} \mathrm{O}, 0.005 \mathrm{MnSO}_{4} \cdot 4 \mathrm{H}_{2} \mathrm{O}, 0.001$ $\mathrm{CoCl}_{2} \cdot 6 \mathrm{H}_{2} \mathrm{O}, 500 \mu \mathrm{l}$ of trace elements and vitamin solution [18]. The $\mathrm{pH}$ of the medium was adjusted to 4.5 with $0.1 \mathrm{~N} \mathrm{NaOH}$. Cultures were incubated at $27{ }^{\circ} \mathrm{C}$ on a rotary shaker ( $125 \mathrm{rpm}$ ) for 14 days. After $24 \mathrm{~h}$ from the inoculation, the putative inducer (i.e. $\mathrm{CuSO}_{4}$ ) was added to liquid cultures at a $1 \mathrm{mM}$ concentration and extracellular fluids were sampled on a daily basis in order to assay laccase activity.

\subsection{Enzyme assay}

Laccase activity was determined spectrophotometrically with 2,2'-azinobis-(3ethylbenzothiazoline-6-sulfonic acid) (ABTS) as substrate and the oxidation was monitored at $436 \mathrm{~nm}\left(\varepsilon 436=36 \mathrm{mmol}^{-1} \mathrm{~cm}^{-1}\right)$ [19]. One unit of enzyme activity was defined as the amount of enzyme that oxidized $1 \mu \mathrm{mol}$ of ABTS $\mathrm{min}^{-1}$.

\subsection{Protein determination}

The protein content of the culture filtrate was estimated by Lowry's method [20] with bovine serum albumin as the standard.

\subsection{Enzyme purification}

For enzyme purification, pre-chilled acetone $\left(4^{\circ} \mathrm{C}\right)$ was added to the culture filtrate $(66 \% \mathrm{v} / \mathrm{v})$ and incubated for $6 \mathrm{~h}$ at $-20^{\circ} \mathrm{C}$. After $6 \mathrm{~h}$, the culture filtrate was centrifuged at $5600 \times g$ for $10 \mathrm{~min}$. The supernatant was decanted and the pellet was dissolved in $0.1 \mathrm{M}$ sodium acetate buffer ( $\mathrm{pH} 4.5$ ) and dialyzed against the same buffer. The dialyzed enzyme preparation was loaded onto a Sephadex G-100 (Fine) column ( $45 \mathrm{~cm} \times 2.5 \mathrm{~cm}$ ) previously equilibrated with $0.1 \mathrm{M}$ sodium acetate buffer $(\mathrm{pH} 4.5$ ) containing $0.1 \mathrm{M} \mathrm{NaCl}$ and eluted with the same buffer at a flow rate of $10.0 \mathrm{ml} \mathrm{h}^{-1}$. In each step, the protein content and laccase activity were determined. The active fractions were pooled, dialyzed against distilled water using a 12,000 Da cut-off dialysis tubing (Sigma, USA) and concentrated by freeze-drying. The concentrated laccase fractions were dissolved in $3.0 \mathrm{ml}$ of $0.1 \mathrm{M}$ sodium acetate buffer ( $\mathrm{pH} 4.5$ ) and loaded onto a Con-A CL Agarose column $(5 \mathrm{~cm} \times 2.5 \mathrm{~cm})$ (Genei, Bangalore, India) pre-equilibrated with $0.1 \mathrm{M}$ sodium acetate buffer containing $0.5 \mathrm{M} \mathrm{NaCl}, 0.1 \mathrm{mM} \mathrm{CaCl}$ and $0.1 \mathrm{mM} \mathrm{MnCl}_{2}$. After being washed with the same buffer, bound proteins were eluted by a linear gradient of $\alpha$-D-methylmannopyranoside from 0 to $0.5 \mathrm{M}$ in equilibrating buffer with a total volume of $30 \mathrm{ml}$. Fractions were collected at a flow rate of $20 \mathrm{ml} \mathrm{h}^{-1}$. The fractions with high laccase activity were pooled, concentrated and stored at $-4{ }^{\circ} \mathrm{C}$. All the purification steps were conducted at temperatures not exceeding $4{ }^{\circ} \mathrm{C}$.

\subsection{Molecular mass}

Sodium dodecyl sulphate-polyacrylamide gel electrophoresis (SDS-PAGE) was used to monitor the development of the purification process, to determine the homogeneity and apparent molecular mass of the purified laccase. SDS-PAGE was carried out on a $10 \%$ resolving gel and a $4 \%$ stacking gel according to the method of Laemmli [21]. Proteins were visualized by staining with Coomassie Brilliant Blue R250 .

\subsection{Absorption spectrum}

The UV-vis absorption spectrum of purified laccase $\left(1 \mathrm{mg} \mathrm{ml}^{-1}\right.$ in $0.1 \mathrm{M}$ sodium acetate buffer, $\mathrm{pH} 4.5$ ) was recorded at $25^{\circ} \mathrm{C}$ on a spectrophotometer (Hitachi, model U-3210, Tokyo) in $2 \mathrm{~cm}$ path length quartz cells.

\subsection{Redox potential}

Cyclic voltammetry (CV) was performed on a $\mathrm{CH}$ instruments electrochemical analyzer, with a platinum disc-working electrode, an $\mathrm{AgCl} / \mathrm{Ag}$ reference electrode and a platinum wire counter electrode. Prior to each voltammetric run, surface cleansing of the working electrode was carried out with alumina according to the manufacturer's instructions. To determine the redox potentials of laccase T1 centers, protein redox titration method [22] was employed with potassium octocyanomolybdate (IV and V) mediators. Laccases were placed anaerobically into a cell containing a high concentration of $\mathrm{K}_{3} \mathrm{Mo}(\mathrm{CN})_{8}$ in $0.1 \mathrm{M}$ sodium acetate buffer, $\mathrm{pH}$ 4.5. Redox potentials were registered with platinum electrodes before and after the addition of enzymes. Further titration was performed with the reduced form of the mediator $\left(\mathrm{K}_{4} \mathrm{Mo}(\mathrm{CN})_{8}\right)$ in $0.1 \mathrm{M}$ sodium acetate buffer, $\mathrm{pH}$ 4.5. The voltammogram was obtained at the scanning rate of $0.1 \mathrm{~V} \mathrm{~s}^{-1}$.

\subsection{Effect of $\mathrm{pH}$ and temperature}

The optimum $\mathrm{pH}$ of the purified enzyme was studied over a pH range of 2.0-10.0. To determine the pH stability, enzyme was kept at $4{ }^{\circ} \mathrm{C}$ for $1 \mathrm{~h}$ in different buffers $(100 \mathrm{mM})$ and the residual laccase activity was determined under standard assay conditions. The buffer systems used were citrate buffer for $\mathrm{pH} 2.0-3.5$; acetate buffer for $\mathrm{pH} 4.0-5.5$; phosphate buffer for $\mathrm{pH}$ 6.0-7.5; Tris- $\mathrm{HCl}$ buffer for $\mathrm{pH} 7.5-$ 9.0; carbonate-bicarbonate buffer for $\mathrm{pH}$ 9.5-10.0. To analyze the effect of temperature, the activity was tested at different temperatures $\left(25-80^{\circ} \mathrm{C}\right)$ by standard enzyme assay (100 mM sodium acetate buffer, $\mathrm{pH} 4.5)$.

\subsection{Thermal stability}

Thermal stability was determined after different pre-incubation times (1-24 h, at 35,55 and $65^{\circ} \mathrm{C}$ ) as the residual activity detectable with ABTS in sodium acetate buffer (100 mM, pH 4.5).

\subsection{Kinetic constants of T. harzianum laccase}

Kinetic constants of laccase for the most commonly used substrates 2,2' azinobis-(3-ethylbenzothiazoline-6-sulfonic acid) and guaiacol was investigated. The rate of aromatic substrate oxidation was determined by spectrophotometry, using reported molar extinction coefficients $(\varepsilon)$. The substrate concentration ranges used were of $100-600 \mu \mathrm{M}$ and $50-300 \mu \mathrm{M}$ for ABTS and guaiacol, respectively. The reactions were conducted at $35^{\circ} \mathrm{C}$. Kinetic studies were conducted for both the substrates and the $V_{\max }$ and $K_{\mathrm{m}}$ values were calculated using the Lineweaver-Burk transformation of Michaelis-Menten equation.

\subsection{Effect of inhibitors on enzyme activity}

The effect of several potential inhibitors such as diethyldithiocarbamic acid (DDC), ethylenediaminetetraacetic acid (EDTA), ethanol, sodium azide $\left(\mathrm{NaN}_{3}\right)$ and thioglycolic acid on laccase activity was monitored. To $1.0 \mathrm{ml}$ of reaction mixture, $800 \mu \mathrm{l}$ of $0.1 \mathrm{M}$ sodium acetate buffer containing ABTS $(0.18 \mathrm{mM}, \mathrm{pH} 4.5), 100 \mu \mathrm{l}$ of enzyme $\left(4.1 \mathrm{U} \mathrm{ml}^{-1}\right)$ and $100 \mu \mathrm{l}$ of inhibitor at various concentrations were added. The reaction mixture was incubated at $35{ }^{\circ} \mathrm{C}$ and the change in absorbance was measured spectrophotometrically at $436 \mathrm{~nm}$. A control test was conducted in parallel in the absence of the inhibitor. 
Table 1

Purification table for the purification of laccase from $T$. harzianum

\begin{tabular}{|c|c|c|c|c|c|}
\hline Purification step & Total protein (mg) & Total activity (U) & $\begin{array}{l}\text { Specific activity } \\
\text { (U mg }{ }^{-1} \text { protein) }\end{array}$ & Yield (\%) & $\begin{array}{l}\text { Purification } \\
\text { factor (fold) }\end{array}$ \\
\hline Culture filtrate & 752.0 & 653.0 & 0.86 & 100 & 1.00 \\
\hline Acetone precipitation & 128.8 & 168.6 & 1.30 & 25.8 & 1.51 \\
\hline Membrane filtration & 20.4 & 52.6 & 2.57 & 8.05 & 2.98 \\
\hline Sephadex G-100 column chromatography & 0.45 & 11.9 & 26.4 & 1.82 & 30.6 \\
\hline Concanavalin-A affinity chromatography & 0.02 & 2.61 & 130.5 & 0.39 & 151.7 \\
\hline
\end{tabular}

\subsection{Effect of metal ions on enzyme activity}

To determine the effect of metal ions on enzyme activity, the reactions were performed by incubating the reaction mixture containing $100 \mu \mathrm{l}$ of enzyme, $800 \mu \mathrm{l}$ of $0.1 \mathrm{M}$ sodium acetate buffer ( $\mathrm{pH} 4.5)$ containing ABTS $(0.18 \mathrm{mM}), 100 \mu \mathrm{l}$ of metal ion solution at $35^{\circ} \mathrm{C}$. Metals, $\mathrm{Co}, \mathrm{Sn}, \mathrm{Hg}, \mathrm{Fe}, \mathrm{K}, \mathrm{Zn}$ Mg, Mn, Na, Ba, $\mathrm{Cr}$ and Ca were used at the concentrations of 1 and $5 \mathrm{mM}$. After incubation, the remaining enzyme activity was assayed. The reaction mixture with heat denatured enzyme served as control.

\section{Results and discussion}

\subsection{Production of laccase}

Laccase production by fungi has been found to be largely affected by culture conditions, such as carbon and nitrogen source and related concentrations and presence or absence of microelements. Laccases are generally produced in low concentrations by fungi, but higher concentrations could be obtained by adding various supplements to liquid growth media $[23,24]$. The onset of laccase activity in T. harzianum occurred on day 2 and reached its maximum on day 4 and then the rate of enzyme production declined gradually. No enzyme production was observed after 8th day (Fig. 1). Supplementation of $\mathrm{CuSO}_{4}$ at $1 \mathrm{mM}$ concentration yielded high amounts of laccase $\left(4.36 \mathrm{U} \mathrm{ml}^{-1}\right)$ at an incubation period of 4 days. These findings are in agreement with previous reports showing that the addition of $2 \mathrm{mM} \mathrm{CuSO}_{4}$ during the exponential growth phase of the fungus led to a remarkably increased laccase production [25,26]. A similar effect was observed in the cultures of Trametes multicolor MB 49 and T. trogii BAFC 463 with copper concentrations ranging from 0.5 to $2.0 \mathrm{mM}$. Addition of inducers enhanced the production of laccase at the level of gene transcription. The promoter regions of the genes encoding for laccase contain various recognition sites that are specific for xenobiotics and heavy metals. It has been demonstrated that the Pleurotus ostreatus laccase genes poxc and poxa1b are transcriptionally induced by copper, and several putative metal responsive

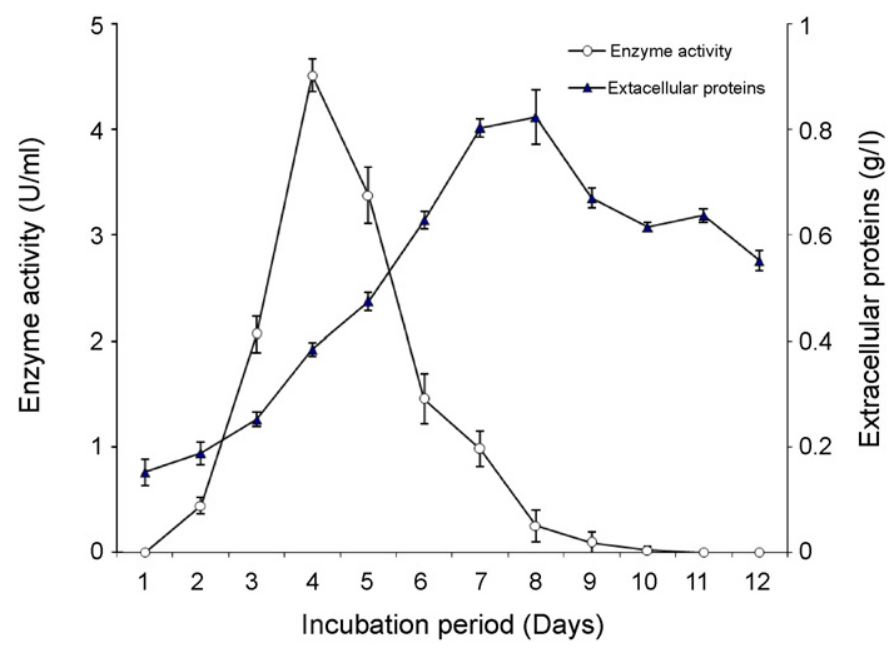

Fig. 1. Time course of extracellular laccase activity. Data points represent the means of three replicates with S.D. of $\pm 5 \%$. elements (MREs) were found in the promoter regions of these genes [27]. The white rot fungus Pycnoporus cinnabarinus produced maximum level of laccase on day 5 and accounted for about $70 \%$ of the total extracellular protein [28]. Under static condition laccase production from Cyathus bulleri was detectable after 2 days and reached maximum on day 7 [29]. The difference in time course of laccase production by the various fungal systems mainly depends on the source, media composition and type of inducers.

\subsection{Purification of laccase}

After removal of the biomass, the supernatant was frozen and thawed. This was necessary in order to remove long chain polysaccharides from the supernatant, which was produced during the growth of the fungus. T. harzianum laccase was purified to homogeneity using a three-step purification procedure as summarized in Table 1. Acetone precipitation followed by Sephadex G-100 column and affinity chromatography on Con-A Agarose enriched the purification of laccase by 151.7 -fold. In Sephadex G-100 column chromatography, the specific activity was increased to $26.4 \mathrm{U} \mathrm{mg}^{-1}$ protein and the yield was $1.82 \%$ with a purification factor of 30.6 fold. The major laccase containing fraction was further purified by Con-A affinity chromatography using $0.25 \mathrm{M} \alpha$-D-methylmannopyranoside as eluent. Among fraction exhibiting laccase activity, only the most active one was collected and displayed a specific activity of $130 \mathrm{U} \mathrm{mg}^{-1}$ protein with a final yield $0.39 \%$. Further, binding of the enzyme to the Concanavalin-A column indicated that the purified laccase might be a mannose-containing glycoprotein. Laccase from Pycnoporus cinnabarinus was purified by Sephacryl S400 gel filtration chromatography with a final purification of 36-fold [28]. Laccase purified from Chaetomium thermophilium by Concanavalin-A affinity chromatography had a specific activity of $37 \mathrm{U} \mathrm{mg}^{-1}$, yield of $40 \%$ with the purification of 10 -fold [30]. Laccase purified from Chalara paradoxa CH32 by Superose 12 has showed a specific activity of $142.4 \mathrm{U} \mathrm{mg}^{-1}$, yield of $7.20 \%$ and a purification factor of 7122.5-fold [31]. Laccase of the ascomycete Mauginiella sp. was purified by ammonium sulfate precipitation followed by anion exchange and hydrophobic interaction chromatography [6].

\subsection{Molecular mass}

The purified T. harzianum laccase showed a single band on SDSPAGE with a mobility corresponding to the molecular mass of $79 \mathrm{kDa}$ as visualized by Coomassie brilliant blue staining (Fig. 2). Its molecular mass appears similar to that of other fungal laccases, which were in the range of $70-80 \mathrm{kDa}[28,30]$. It was reported that the molecular weights of laccases usually ranges from 55 to $90 \mathrm{kDa}$ including carbohydrates [32].

\subsection{Absorption spectrum of T. harzianum laccase}

The UV-vis spectrum of the purified T. harzianum laccase (Fig. 3) showed a peak of absorption at around $608 \mathrm{~nm}$, typical for the type $\mathrm{I} \mathrm{Cu}(\mathrm{II})$, which is responsible for the deep blue colour of the enzyme [33]. A shoulder at around $325 \mathrm{~nm}$ suggests the presence of the 


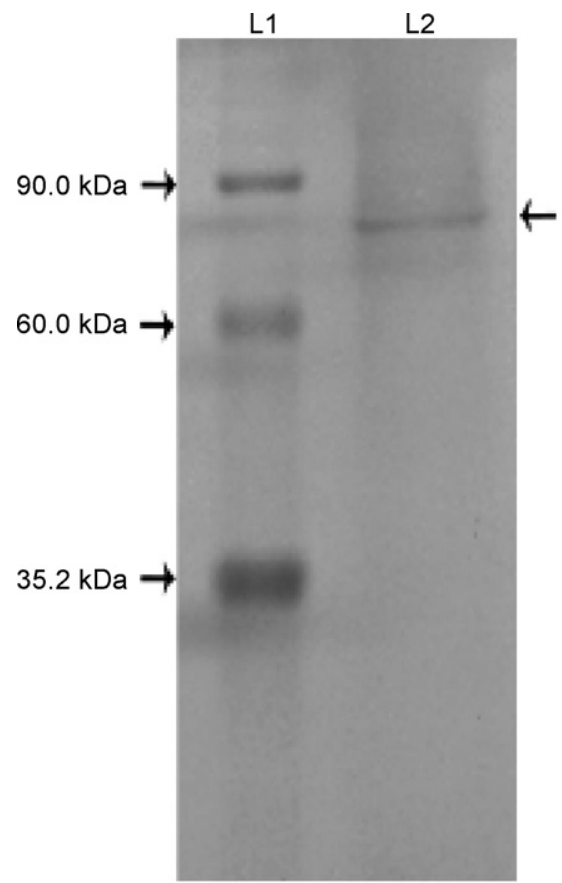

L1 - Molecular mass protein markers

\section{L2 - Purified T. harzianum laccase $(10 \mu \mathrm{g})$}

Fig. 2. SDS-PAGE of purified laccase. L1, molecular mass protein markers; L2, purified $T$. harzianum laccase $(10 \mu \mathrm{g})$.

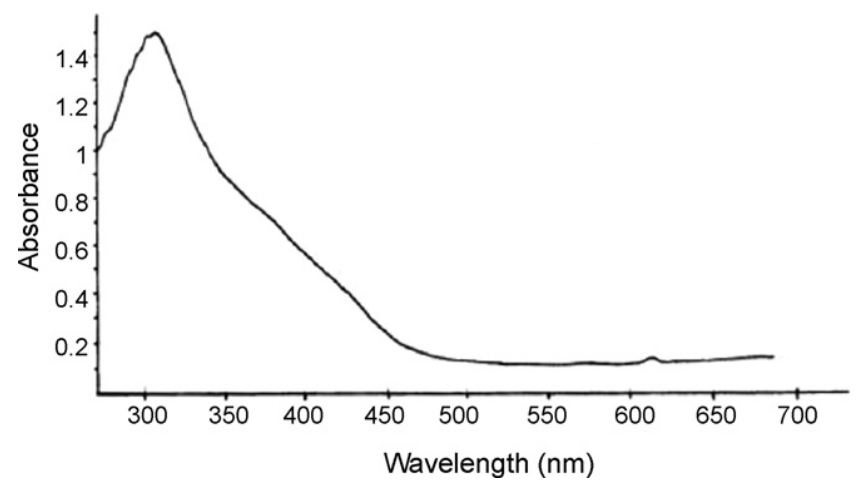

Fig. 3. UV-vis absorption spectrum of the purified laccase from T. harzianum.

type III binuclear $\mathrm{Cu}(\mathrm{II})$ pair [34]. The spectral characteristics of laccase from $T$. harzianum were similar to that observed for other fungal laccases $[6,8]$.

\subsection{Redox potential}

From an electrochemical point of view as well as from the analysis of the primary structure of the enzymes, laccases can be divided into three groups as a function of the potential of the T1 site: low, middle and high potential laccases. The low-redox potential laccases was mainly found in trees and fungi. For an example Rhus vernicifera laccase had a T1 site potential of about $430 \mathrm{mV}$ vs. normal hydrogen electrode (NHE) [35]. The middle group includes laccases from ascomycetes and basidiomycetes fungi, Myceliophthora thermophila and Coprinus cinereus, respectively [36,37]. These enzymes have $\mathrm{T} 1$ site potentials ranging from 470 to $710 \mathrm{mV}$ vs. NHE. All the high potential laccases (those from T. hirsuta, T. versicolor and Trametes villosa) have T1 site potentials
Table 2

Comparison of the redox potentials $\left(E^{\circ}\right)$ of the T1 site of laccases from different sources

\begin{tabular}{lll}
\hline Source & $E^{\circ}, \mathrm{T} 1(\mathrm{mV})$ & Reference \\
\hline Trametes ochracea & $790 \pm 10$ & {$[8]$} \\
Cerrena maxima & $750 \pm 5$ & {$[8]$} \\
Trametes versicolor & 780 & {$[35]$} \\
Rhus vernicifera & 430 & {$[35]$} \\
Trametes villosa & 780 & {$[36]$} \\
Rhizoctonia solani & 710 & {$[36]$} \\
Coprinus cinereus & 550 & {$[37]$} \\
Trametes hirsute & 780 & {$[38]$} \\
Marasmius quercophilus C30 (I) & 730 & {$[39]$} \\
Trametes pubescens Lac I & 746 & Present study \\
Trichoderma harzianum & 692 &
\end{tabular}

of about $780 \mathrm{mV}$ vs. NHE [35,36]. The structural reasons underlying the variability in redox potentials among laccases from different sources has not been fully elucidated. Laccase of $T$. harzianum was observed to have redox potential $\left(E^{\circ}\right)$ of $692 \mathrm{mV}$ for the type $1 \mathrm{Cu}$ (T1) site. Hence, T. harzianum laccase seems to belong to a group of middle redox potential laccases. A comparison of the redox potential of $T$. harzianum laccase isolated in the present study with laccases from different sources was presented in Table 2 .

It was suggested that the value of the redox potentials of the copper-containing oxidases depends on the ligands of the T1 copper and on the amino acids, which form the T1 pocket [41]. The middle redox potentials of Trametes ochracea and Coriolopsis fulvocinerea laccases were mainly due to the significant distances between the amino acids, glutamic acid and alanine [8].

\subsection{Effect of $\mathrm{pH}$ and temperature on enzyme activity}

The optimum $\mathrm{pH}$ for the maximum laccase activity was observed at 4.5 when ABTS was used as substrate. At pH values larger than 4.5 , the enzyme activity decreased gradually and completely inactivated at higher alkaline pH (Fig. 4). This phenomenon can be explained by the difference in redox potential between a reducing substrate and the type 1 copper in the active site of the enzyme and the inhibition of type 3 copper by hydroxide ion at higher $\mathrm{pH}$ [42]. Studies with laccases from Coriolus hirsutus, Trichoderma atroviride, Chalara (syn. Thielaviopsis) paradoxa $\mathrm{CH} 32$ and Cerrena unicolor 059 showed that the optimal pH range for fungal laccase was from 4.0 to $6.0[13,31,43]$.

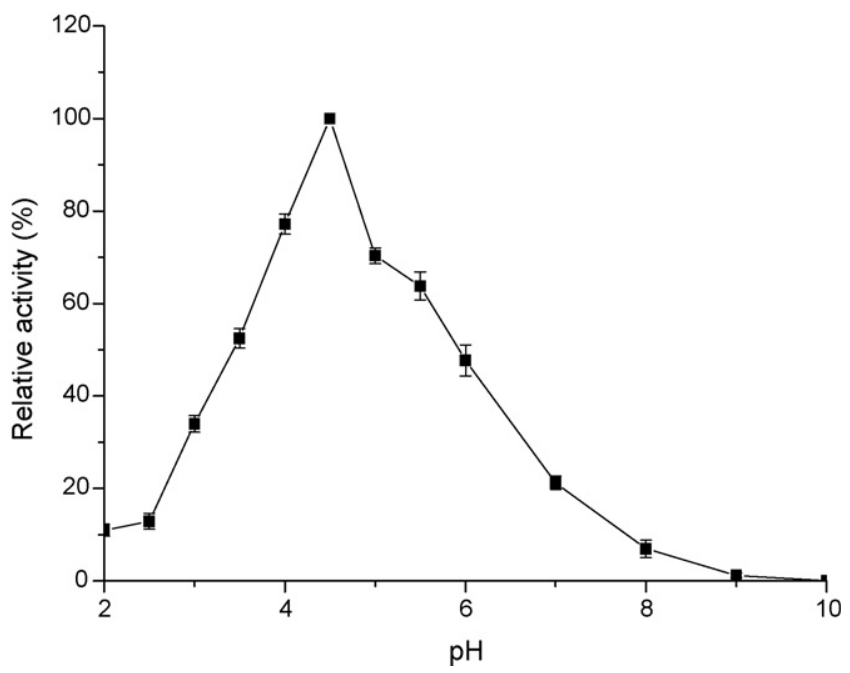

Fig. 4. The effect of $\mathrm{pH}$ on the activity of $\boldsymbol{T}$. harzianum laccase. Data points represent the means of three replicates with S.D. of $\pm 2.5 \%$. 


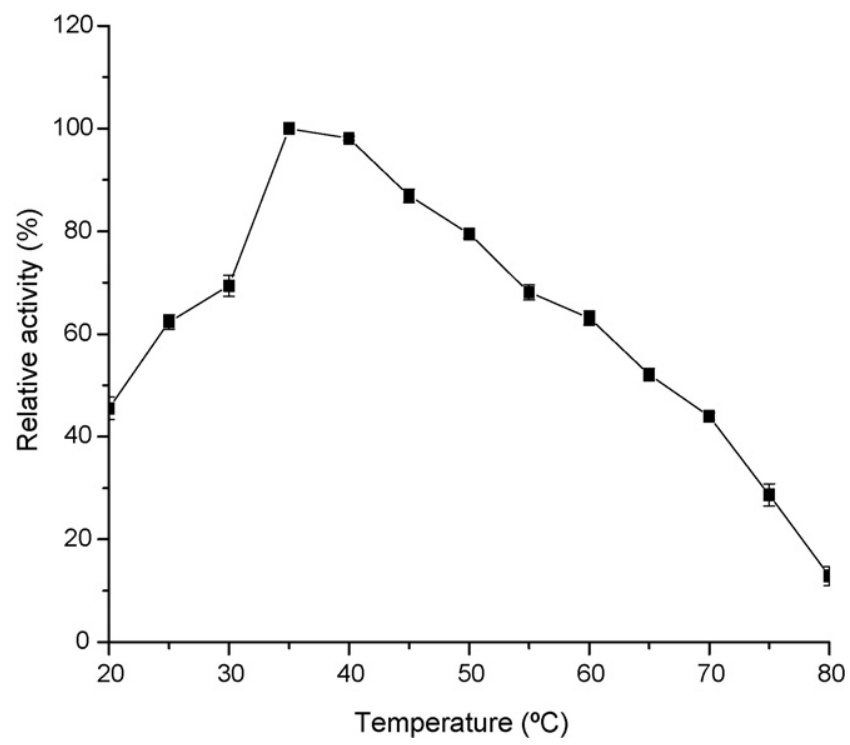

Fig. 5. The effect of temperature on the activity of T. harzianum laccase. Data points represent the means of three replicates with S.D. of $\pm 2.5 \%$.

When laccase activity was studied as a function of temperature, the enzyme was found to be active in a temperature range of 30$50{ }^{\circ} \mathrm{C}$, with the maximum activity at $35^{\circ} \mathrm{C}$ (Fig. 5). In general, laccases are stable at $30-50{ }^{\circ} \mathrm{C}$ and rapidly lose activity at temperatures above $60^{\circ} \mathrm{C}[6,36]$. The laccase from Rigidoporus lignosus was almost fully active in a temperature range of $30-50{ }^{\circ} \mathrm{C}$, with the maximum activity at $40{ }^{\circ} \mathrm{C}$ [44]. The optimum temperature for laccase from the edible mushroom Lentinula edodes at $40^{\circ} \mathrm{C}$ [45].

The stability of the enzyme with respect to temperature was also studied. The T. harzianum laccase retained $70 \%$ of its initial activity after $1 \mathrm{~h}$ incubation at $55^{\circ} \mathrm{C}$; whereas the half-life $\left(t_{1 / 2}\right)$ of enzyme was about $1 \mathrm{~h}$ at $65^{\circ} \mathrm{C}$ and it was completely inactivated after $6 \mathrm{~h}$ incubation. No significant decrease over enzyme activity was observed even after $24 \mathrm{~h}$ incubation at $35^{\circ} \mathrm{C}$ (Fig. 6). It has been reported that temperature stability of laccases varies considerably depending on the source organism. The typical half-life of fungal laccases is below $1 \mathrm{~h}$ at $70{ }^{\circ} \mathrm{C}$ and below $10 \mathrm{~min}$ at $80^{\circ} \mathrm{C}$ [46]. Pycnoporus cinnabarinus laccase was very stable below $50{ }^{\circ} \mathrm{C}$ and at $70^{\circ} \mathrm{C}$ the half-life of the enzyme was about $60 \mathrm{~min}$; whereas at $80^{\circ} \mathrm{C}$, the laccase was completely inactivated [28]. The results obtained in the present study, concurred with these observations.

\subsection{Kinetic constants of $\mathbf{T}$. harzianum laccase}

Laccases are considered to be non-specific to their substrates, being able to oxidize a wide range of aromatic compounds is of interest in delignification, textile dye bleaching and the detoxification of contaminated soil and water. For this reason, in the present work to study the kinetics of laccase activity two different substrates ABTS and monomethoxy-substituted phenolic substrate guaiacol were used. The main kinetic parameters, $V_{\max }$ (maximum enzyme velocity) and $K_{\mathrm{m}}$ (affinity constant) were

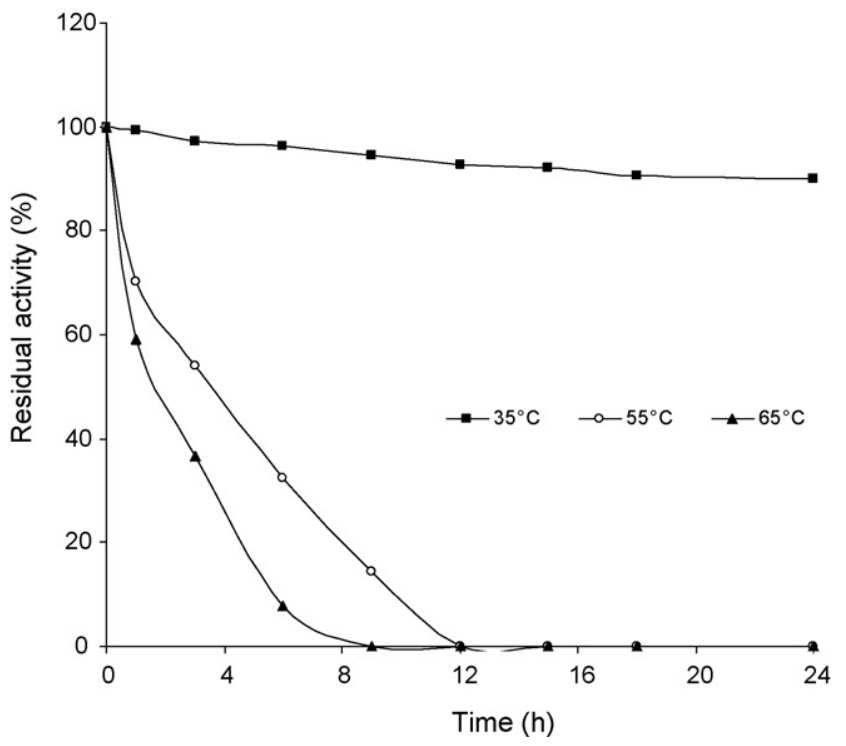

Fig. 6. Thermal stability of T. harzianum laccase. Data points represent the means of three replicates with S.D. of $\pm 2.5 \%$.

determined (Table 3 ). The $V_{\max }$ and $K_{\mathrm{m}}$ values were 3.95, $1.42 \mu \mathrm{mol} \mathrm{min}^{-1} \mathrm{mg}^{-1}$ and 180 and $60 \mu \mathrm{M}$, respectively, for ABTS and guaiacol. ABTS was more efficiently oxidized than guaiacol. This suggests a different behavior of the enzyme for these substrates, which may be correlated to their structures. Laccase from Chaetomium thermophilum had $V_{\max }$ value of $2.6 \mu \mathrm{mol}$ $\mathrm{min}^{-1} \mathrm{mg}^{-1}$ for the substrate ABTS [30]. The fungus Coriolus hirsutus laccase had $K_{\mathrm{m}}$ value of $62.9 \mu \mathrm{M}$ for guaiacol [43]. The Ganoderma lucidum laccase had $K_{\mathrm{m}}$ value of $3.7 \mu \mathrm{M}$ for ABTS [47]. The $K_{\mathrm{m}}$ value for laccases from Pleurotus sajor-caju was $0.092 \mathrm{mM}$ against ABTS [48]. Pleurotus pulmonarius laccase showed the apparent $K_{\mathrm{m}}$ value for ABTS as $210 \mu \mathrm{M}$ [49]. The values of the catalytic constants obtained for $T$. harzianum laccase were markedly higher than the above reported fungal laccases, which indicates the higher substrate specificity of laccase from Trichoderma harzianum.

\subsection{Effect of inhibitors on laccase activity}

Effect of a range of potent laccase inhibitors on the enzyme activity was tested with ABTS as substrate and the results were presented in Table 4 . Addition of water miscible solvents such as ethanol caused a net decrease in enzyme activity, when its concentration exceeds above $20 \%$. Thioglycolic acid inhibited $92.4 \%$ of enzyme activity at the concentration of $750 \mu \mathrm{M}$. In general, organic solvents alter the $\mathrm{pH}$ of aqueous solution and there by affect the enzyme activity [50]. Laccase activity was completely inhibited by the common metalloenzyme inhibitor, sodium azide $\left(\mathrm{NaN}_{3}\right)$ at the concentration of $20 \mu \mathrm{M}$. It was reported that the binding of sodium azide to the types 2 and 3 copper sites affects internal electron transfer, thus inhibiting the activity of laccase [51]. T. harzianum laccase was mildly inhibited by the metal chelator EDTA ( $5 \mathrm{mM}$ ) and more strongly inhibited by the copper chelator diethyldithiocarbamic acid (DDC) at $1 \mathrm{mM}$ concentration.

Table 3

Kinetic parameters for laccase from T. harzianum

\begin{tabular}{|c|c|c|c|c|c|c|}
\hline Substrate & $\begin{array}{l}\text { Wavelength } \\
\left(\lambda_{\max }, \mathrm{nm}\right)\end{array}$ & Assay pH & $\begin{array}{l}\text { Molar extinction } \\
\text { coefficient } \varepsilon\left(\mathrm{M}^{-1} \mathrm{~cm}^{-1}\right)\end{array}$ & $K_{\mathrm{m}}(\mu \mathrm{M})$ & 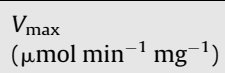 & $V_{\max } / K_{\mathrm{m}}$ \\
\hline ABTS & 436 & 4.5 & 29,300 & 180 & 3.95 & 21.94 \\
\hline Guaiacol & 470 & 4.5 & 12,000 & 60 & 1.42 & 23.66 \\
\hline
\end{tabular}


Table 4

Effect of inhibitors on laccase activity

\begin{tabular}{lcc}
\hline Inhibitor & Concentration & \% Inhibition \\
\hline Diethyldithiocarbamic acid (DDC) $(\mathrm{mM})$ & 0.1 & 25.9 \\
& 0.2 & 34.5 \\
& 0.5 & 59.2 \\
Ethylenediaminetetraacetic acid (EDTA) $(\mathrm{mM})$ & 1.0 & 99.8 \\
& 1 & 16.8 \\
& 5 & 40.3 \\
Ethanol (\%) & 10 & 62.8 \\
& 25 & 94.5 \\
& 10 & 3.4 \\
Sodium azide $\left(\mathrm{NaN}_{3}\right)(\mu \mathrm{M})$ & 20 & 8.9 \\
& 50 & 100 \\
& 70 & 14.0 \\
Thioglycolic acid $(\mathrm{TGA})(\mu \mathrm{M})$ & 2 & 38.7 \\
& 5 & 69.2 \\
& 10 & 100 \\
& 20 & 13.3 \\
& 100 & 32.6 \\
& 250 & 54.1 \\
& 500 & 92.4 \\
\hline
\end{tabular}

Laccase activity was strongly inhibited by metal specific chelators rather than by general metal chelators.

\subsection{Effect of metal ions on laccase activity}

The interaction of metals with extracellular laccase was particularly important for the better understanding of the biotechnological processes of xenobiotic degradation. Therefore, the stability of laccase activity against several metal compounds was tested (Table 5). Metals such as $\mathrm{Co}, \mathrm{Sn}, \mathrm{Hg}, \mathrm{Fe}, \mathrm{K}, \mathrm{Zn} \mathrm{Mg}, \mathrm{Mn}$, $\mathrm{Na}, \mathrm{Ba}, \mathrm{Cr}$ and $\mathrm{Ca}$ were assessed. Metal ion concentration of $1 \mathrm{mM}$

Table 5

Effect of metal ions on laccase activity

\begin{tabular}{|c|c|c|}
\hline Metal ion & Concentration (mM) & $\%$ Inhibition \\
\hline \multirow[t]{2}{*}{ Cobalt } & 1 & 1.8 \\
\hline & 5 & 3.6 \\
\hline \multirow[t]{2}{*}{ Tin } & 1 & 1.1 \\
\hline & 5 & 9.7 \\
\hline \multirow[t]{2}{*}{ Mercury } & 1 & 17.2 \\
\hline & 5 & 25.4 \\
\hline \multirow[t]{2}{*}{ Ferric } & 1 & 1.5 \\
\hline & 5 & 2.0 \\
\hline \multirow[t]{2}{*}{ Potassium } & 1 & 3.3 \\
\hline & 5 & 3.9 \\
\hline \multirow{2}{*}{ Zinc } & 1 & 7.6 \\
\hline & 5 & 11.4 \\
\hline \multirow[t]{2}{*}{ Magnesium } & 1 & 1.4 \\
\hline & 5 & 2.8 \\
\hline \multirow[t]{2}{*}{ Manganese } & 1 & 0.8 \\
\hline & 5 & 1.2 \\
\hline \multirow[t]{2}{*}{ Sodium } & 1 & Nil \\
\hline & 5 & Nil \\
\hline \multirow[t]{2}{*}{ Barium } & 1 & Nil \\
\hline & 5 & 0.6 \\
\hline \multirow[t]{2}{*}{ Chromium } & 1 & 1.7 \\
\hline & 5 & 13.8 \\
\hline \multirow[t]{2}{*}{ Calcium } & 1 & 0.6 \\
\hline & 5 & 3.5 \\
\hline
\end{tabular}

had no significant effect over laccase activity except $\mathrm{Hg}$, which caused $17.2 \%$ inhibition. When the metal ion concentration was increased to $5 \mathrm{mM}, \mathrm{Cr}, \mathrm{Zn}$ and $\mathrm{Sn}$ inhibited laccase activity by 13.8 , 11.4 and $9.7 \%$, respectively; whereas the laccase activity was highly sensitive to $5 \mathrm{mM} \mathrm{Hg}$ showing $25.4 \%$ inhibition, indicating the presence of thiol groups, essential for its activity. The purified laccase from the edible mushroom Lentinula edodes was inhibited in the presence of $1 \mathrm{mM} \mathrm{Sn}{ }^{2+}(99 \%), \mathrm{Ca}^{2+}(70 \%), \mathrm{Zn}^{2+}(64 \%), \mathrm{Hg}^{2+}$ (55\%), $\mathrm{K}^{+}(54 \%)$ and $\mathrm{Cd}^{2+}(45 \%)$ and it was activated by $40 \%$ in the presence of $10 \mathrm{mM} \mathrm{Cu}^{2+}$. The activation of laccase by $\mathrm{Cu}^{2+}$ may be due to the filling of type-2 copper binding sites with copper ions [45]. The observations indicated that the effect of metal ions on laccase activity was highly dependent on its source and the type of metals used, which had a great influence on the catalytic activity of the enzyme. The activation or inhibition of proteolytic enzymes by metals could change the turnover rate of extracellular enzymes.

\section{References}

[1] Bollag JM, Leonowicz A. Comparative studies of extracellular fungal laccases. Appl Environ Microbiol 1984;48:849-54.

[2] Revankar MS, Lele SS. Enhanced production of laccase using a new isolate of white rot fungus WR-1. Process Biochem 2006;41:581-8.

[3] Kiiskinen LL, Rättö M, Kruus K. Screening for novel laccase-producing microbes. J Appl Microbiol 2004;97:640-6.

[4] Liers C, Ullrich R, Pecyna M, Schlosser D, Hofrichter M. Production, purification and partial enzymatic and molecular characterization of a laccase from the wood-rotting ascomycete Xylaria polymorpha. Enzyme Microb Technol 2007;41:785-93.

[5] Wood DA. Production, purification and properties of extracellular laccase of Agaricus bisporus. J Gen Microbiol 1980;117:327-38.

[6] Palonen H, Saloheimo M, Viikari L, Kruus K. Purification, characterization and sequence analysis of a laccase from the ascomycete Mauginiella sp. Enzyme Microb Technol 2003;33:854-62.

[7] Garzillo AMV, Paola SD, Burla G, Buonocore V. Differentially induced extracellular phenol oxidases from Pleurotus ostreatus. Phytochemistry 1992;31: 3685-90.

[8] Shleev SV, Morozova OV, Nikitina OV, Gorshina ES, Rusinova TV, Serezhenkov VA, et al. Comparison of physico-chemical characteristics of four laccases from different basidiomycetes. Biochimie 2004;86:693-703.

[9] Palmer AE, Randall DW, Xu F, Solomon EI. Spectroscopic studies and electronic structure description of the high potential type 1 copper site in fungal laccase: insight into the effect of the axial ligand. J Am Chem Soc 1999;121:7138-49.

[10] Johannes C, Majcherczjk A. Natural mediators in the oxidation of polycyclic aromatic hydrocarbons by laccase mediator systems. Appl Environ Microbiol 2000;66:524-8.

[11] Nyanhongo GS, Gomes J, Gubitz GM, Zvauya R, Read J, Steiner W. Decolorization of textile dyes by laccase from a newly isolated strain of Trametes modesta. Water Res 2002:36:1449-56.

[12] Pickard MA, Roman R, Tinoco R, Vazquez-Duhalt R. Polycyclic aromatic hydrocarbons metabolism by white rot fungi and oxidation by Coriolopsis gallica UAMH 8260 laccase. Appl Environ Microbiol 1999;65:3805-9.

[13] Holker U, Dohse J, Hofer M. Extracellular laccases in ascomycetes Trichoderma atroviride and Trichoderma harzianum. Folia Microbiol 2002;47:423-7.

[14] Assavanig A, Amornkitticharoen B, Ekpaisal N, Meevootisom V, Flegel TM. Isolation, characterization and function of laccase from Trichoderma. Appl Microbiol Biotechnol 1992;38:198-202.

[15] Sadhasivam S, Savitha S, Swaminathan K. Feasibility of using Trichoderma harzianum biomass for the removal of erioglaucine from aqueous solution. World J Microbiol Biotechnol 2007;23:1075-81.

[16] Rifai M. A Revision of Genus Trichoderma. Mycol Papers 1969;116:1-56.

[17] Kirk TK, Schultz E, Connors WJ, Lorenz LF, Zeikus JG. Influence of culture parameters on lignin metabolism by Phanerochaete chrysosporium. Arch Microbiol 1978;117:277-85.

[18] Cavalitto SF, Hours RA, Mignone CF. Growth and protopectinase production of Geotrichum klebahnii in batch and continuous cultures with synthetic media. J Ind Microbiol Biotechnol 2000;25:260-5.

[19] Wolfenden BS, Wilson RL. Radical cations as reference chromogens in studies of one-electron transfer reactions; pulse radiolysis studies of 2,2'-azinobis-(3ethylbenzothiazoline-6-sulfonate). J Chem Soc Perkin Trans 1982;11:805-12.

[20] Lowry RJ, Rosebrough NJ, Farr AL, Randall RJ. Protein measurement with the Folin phenol reagent. J Biol Chem 1951;193:265-75.

[21] Laemmli UK. Cleavage of structural proteins during the assembly of the head of bacteriophage T4. Nature 1970;227:680-5.

[22] Dutton PL. Redox potentiometry: determination of midpoint potentials of oxidation-reduction components of biological electron-transfer systems. Methods Enzymol 1978;54:411-35.

[23] Lee IY, Jung KH, Lee CH, Park YH. Enhanced production of laccase in Trametes versicolor by the addition of ethanol. Biotechnol Lett 1999;21:965-8. 
[24] Vasconcelos AF, Barbosa AM, Dekker RFH, Scarminio IS, Rezende MI. Optimization of laccase production by Botryospaeria sp. in the presence of veratryl alcohol by the response-surface method. Process Biochem 2000;35:1131-8.

[25] Galhaup C, Wagner H, Hinterstoisser B, Haltrich D. Increased production of laccase by the wood-degrading basidiomycete Trametes pubescens. Enzyme Microb Technol 2002;30:529-36.

[26] Rodriguez Couto S, Sanroman MA. Coconut flesh: a novel raw material for laccase production by Trametes hirsuta under solid state conditions. Application to Lissamine Green B decolorization. J Food Eng 2005;71:208-13.

[27] Faraco V, Giardina P, Sannia G. Metal-responsive elements in Pleurotus ostreatus laccase gene promoters. Microbiology 2003;149:2155-62.

[28] Eggert C, Temp U, Eriksson KEL. The ligninolytic system of the white rot fungus Pycnoporus cinnabarinus: purification and characterization of the laccase. Appl Environ Microbiol 1996;62:1151-8.

[29] Vasdev K, Kuhad RC. Induction of laccase production in Cyathus bulleri under shaking and static culture conditions. Folia Microbiol 1994;39:326-30.

[30] Chefetz B, Chen Y, Hadar Y. Purification and characterization of laccase from Chaetomium thermophilium and its role in humification. Appl Environ Microbiol 1998;64:3175-9.

[31] Robles A, Lucas R, Martinez-Canamero M, Omar NB, Perez R, Galvez A Characterisation of laccase activity produced by the hyphomycete Chalara (syn. Thielaviopsis) paradoxa CH 32. Enzyme Microb Technol 2002;31:516-22.

[32] Peter MG, Wollenberger U. Phenol-oxidizing enzymes: mechanisms and applications in biosensors. In: Scheller FW, Schubert F, Fedrowitz J, editors. Frontiers in biosensorics vol 1 EXS 80, Basel: Birkhauser; 1997. p. 63-82.

[33] Reinhammar B, Malmstrom BG. "Blue"-copper-containing oxidases. In: Spiro TG, editor. Copper proteins. New York: Wiley-Interscience; 1981. p. 109-49.

[34] Reinhammar B. Laccase. In: Lontie R, editor. Copper proteins and copper enzymes, vol. 3. Boca Raton, FL: CRC Press; 1984. p. 1-35.

[35] Reinhammar BRM. Oxidation-reduction potentials of the electron acceptors in laccases and stellacyanin. Biochim Biophys Acta 1972;275:245-59.

[36] Xu F, Shin W, Brown SH, Wahleitner JA, Sundaram UM, Solomon EI. A study of recombinant fungal laccases and bilirubin oxidase that exhibit significant differences in redox potential, substrate specificity, and stability. Biochim Biophys Acta 1996;1292:303-11.

[37] Schneider P, Caspersen MB, Mondorf K, Halkier T, Skov LK, Ostergaard PR. Characterization of a Coprinus cinereus laccase. Enzyme Microb Technol 1999;25:502-8

[38] Kojima Y, Tsukuda Y, Kawai Y, Tsukamoto A, Sugiura J, Sakaino M, et al. Cloning, sequence analysis, and expression of lignolytic phenoloxidase genes of the white-rot basidiomycete Coriolus hirsutus. J Biol Chem 1990;265:15224-30.
[39] Klonowska A, Gaudin C, Fournel A, Asso M, Le Petit J, Giorgi M, et al. Characterization of a low redox potential laccase from the basidiomycete C30. Eur J Biochem 2002;269:6119-25.

[40] Shleev SV, Nikitina OV, Christenson A, Reimann CT, Yaropolov AI, Ruzgas T, et al. Characterization of two new multiforms of Trametes pubescens laccase Bioorg Chem 2007;35:35-49.

[41] Xu F, Berka RM, Wahleithner JA, Nelson BA, Shuster JR, Brown SH, et al. Sitedirected mutations in fungal laccase: effect on redox potential, activity and $\mathrm{pH}$ profile. Biochem J 1998;334:64-70.

[42] Xu F. Effect of redox potential and hydroxide inhibition on the pH activity profile of fungal laccases. J Biol Chem 1997;272:924-8.

[43] Koroljova-Skorobogat'ko OV, Stepanova EV, Gavrilova VP, Morozova OV, Lubimova NV, Dzchafarova AN, et al. Purification and characterization of the constitutive form of laccase from the basidiomycete Coriolus hirsutus and the effect of inducers on laccase synthesis. Biotechnol Appl Biochem 1998;28:47-54

[44] Cambria MT, Cambria A, Ragusa S, Rizzarelli E. Production, purification, and properties of an extracellular laccase from Rigidoporus lignosus. Protein Express Purif 2000;18:141-7.

[45] Nagai M, Sato T, watanabe H, Saito K, Kawata M, Enei H. Purification and characterization of an extracellular laccase from the edible mushroom Lentinula edodes, and decolorization of chemically different dyes. Appl Microbiol Technol 2002;60:327-35.

[46] Jung $\mathrm{H}, \mathrm{Xu}$ F, Li K. Purification and characterization of laccase from wooddegrading fungus Trichopyton rubrum LKY-7. Enzyme Microb Technol 2002;30:161-8.

[47] Ko EM, Leem YE, Choi HT. Purification and characterization of laccase isozymes from the white rot basidiomycete Ganoderma lucidum. Appl Microbiol Biotechnol 2001;57:98-102.

[48] Lo SC, Ho YS, Buswell JA. Effect of phenolic monomers on the production of laccases by the edible mushroom Pleurotus sajor-caju and partial characterization of a major laccase component. Mycologia 2001;93:413-21.

[49] De Souza CGM, Peralta RM. Purification and characterization of the main laccase produced by the white rot fungus Pleurotus pulmonarius on wheat bran solid state medium. J Basic Microbiol 2003;43:278-86.

[50] Rodakiewicz-Nowak J, Kasture SM, Dudek B, Haber J. Effect of various watermiscible solvents on enzymatic activity of fungal laccases. J Mol Catal B-Enzym 2002;11:1-11.

[51] Ryan S, Schnitzhufer W, Tzanov T, Cavaco-Paulo A, Gubitz GM. An acid-stable laccase from Sclerotium rolfsii with potential for wool dye decolourization. Enzyme Microb Technol 2003;33:766-74. 